\title{
Men that Buy Inequality: Critical Analysis of Sex Buyers' Discourse on Prostituted Women and Girls
}

\author{
Hombres que compran desigualdad: análisis crítico del \\ discurso de los sujetos prostituyentes sobre mujeres y \\ niñas prostituidas
}

\begin{abstract}
Over the centuries, prostitution has been problematised from many sides, with women always at the centre of the debate. However, its dynamics cannot be understood without the demand side of the equation. Why are there men that pay for prostitution to exist? The purpose of this paper is to give insight into the mindset of men who seek out prostitution services by critically analysing the discourse they produce online. Sex buyers' expectations in commercial sexual encounters with prostituted women are a good insight into their belief system about women in general. Such expectations are likely to have practical consequences in the way they behave in their relationships with all women in terms of sexuality and, therefore, for feminist purposes of equality on a broader scale.
\end{abstract}

Keywords: Prostitution, masculinity, power relations, discourse analysis.

\section{RESUMEN}

Durante siglos, la prostitución ha sido problematizada desde muchos ángulos, con las mujeres siempre en el centro del debate. Sin embargo, sus dinámicas no pueden ser comprendidas sin un análisis de la demanda. ¿Por qué hay hombres que pagan para que la prostitución exista? El objetivo de este artículo es ahondar en su manera de pensar mediante un análisis crítico del discurso que ellos mismos producen. Las expectativas que estos hombres tienen de cara a los encuentros sexuales comerciales con mujeres prostituidas son una ventana a su sistema de creencias sobre las mujeres en general. Tales expectativas tienen consecuencias prácticas en la manera en que actúan con todas las mujeres dentro del marco de la sexualidad y, por tanto, afecta a la lucha por la igualdad fáctica entre hombres y mujeres a nivel social.

Palabras clave: Prostitución, masculinidad, relaciones de poder, análisis del discurso.

\section{SUMMARY}

- Introduction. 1.- Patriarchal masculinity, sexual violence, and prostitution as a gendered phenomenon. 2.- Methodology and a note on terminology. 3.- Analysis of buyer-authored reviews on prostituted women and girls. - Conclusions. - Bibliography. 


\section{Introduction}

Women have always been at the centre of the numerous debates about prostitution. In the last decades, an increasing number of studies, some with an explicit feminist standpoint, have addressed prostitution with a focus on men's demand. Such is the case of this paper. Currently, there are many virtual communities of sex buyers on the Internet. After a general screening of several Ireland-andUK-based sites, the one selected for this analysis was www.PunterNet.com, one of the most popular websites among them. ${ }^{2}$ The analysis of sex buyers' discourse provided the opportunity to verify whether the relationship they establish with the women they purchase for sex is based on a form of democratic mutual equality (similar to the one a customer can establish with a taxi driver, a hairdresser or other kinds of «service providers») or if such relationship is addressed in terms of dichotomic, gendered, power relations based on domination and subordination.

Following the contextualisation of the issue, with a critical approach to the hegemonic, patriarchal type of masculinity, the essentialist account on male sexuality, and the gendered character of prostitution, a summarised analysis of online reviews written in www.PunterNet.com by sex buyers will be presented. ${ }^{3}$ This analysis, carried out by means of Critical Discourse Analysis (CDA), aimed to identify the main tenets of the power-structures implied in discourse. A critical discourse analysis of the selected samples allowed the discovery of the patterns that characterise positive and negative reviews, which are inevitably linked to the kind of things sex buyers want, require and expect from prostituted women and girls and, conversely, the kind of things they do not want, require and expect. Observing how they communicate among themselves revealed the assumptions that form a set of beliefs common to sex buyers about prostituted women and girls, and insight into their belief system about women in general. The article exposes a number of relevant issues that arise from the analysis of sex buyers' discourse that affect feminist purposes of equality at a larger scale.

2 It was created in 1999 and presents itself as "The UK's oldest escort directory and review site." In 2009, Harriet Harman, Minister for Women and Equality at that time, announced that, in it, "pimps put women on sale for sex and then men who've had sex with them put their comments online", which was putting women at risk. Its domain is based in California, so it is protected by the United States Constitution and its guaranteed right of free speech.

3 For more information on the methodology, the selection of data and an extended analysis of the reviews see Senent (2017). 


\section{Patriarchal masculinity, sexual violence, and prostitution as a gendered phenomenon}

In the $18^{\text {th }}$ century, philosopher and political economist Bernard Mandeville wrote AModest Defence of Public Stews: Prostitution and its discontents in Early Georgian England, where he proclaimed the necessity of sacrificing one part of womankind to preserve the other. In his own words:

Observe the Policy of a Modern Butcher, persecuted with a Swarm of Carnivorous Flies; where all his Engines and Fly-Flaps have prov'd ineffectual to defend his Stall against the Greedy Assiduity of those Carnal Insects, he very Judiciously cuts off a Fragment, already blown, which serves to hang up for a Cure; and thus, by Sacrificing a Small Part, already Tainted, and now worth Keeping, he wisely secures the Safety of the Rest (cited in Grant, 2012: 105).

Mandeville's opinion, according to which prostituted women are like the rotten meat a butcher should leave aside if he is to preserve his healthy stock from flies, is alive and well in our days. ${ }^{4}$ Often called the "oldest profession", prostitution has been regarded as inevitable, unquestionable, and the women involved in it treated as loose, sick or fallen women, unworthy of respect. Over the centuries, the demand side of the equation has been utterly ignored, something that has been put under question by an increasing number of authors (Månsson, 2001; Salazar, 2017) and an essentialist account on male sexuality has legitimated and perpetuated the assumption that male sexual violence must be purposely directed towards a specific, pointed, group of women (prostitutes) for other women (non-prostitutes) to be «safe» from it.

Gender relations are historical, which means the current gender-based hierarchies are a specific social and historical product. The concept of hegemonic masculinity ${ }^{5}$ is understood as the pattern of practice that ideologically legitimates men's collective dominance over women. In some contexts, it refers to men's toxic practices that can include physical violence and that stabilise gender dominance (Connell \& Messerschmidt, 2005: 840). The number of men rigorously practising the hegemonic pattern of masculinity «may be quite small», but the majority "gain from its hegemony, since they benefit from the patriarchal dividend, ${ }^{6}$ the advantage men in general gain from the overall subordination of women». There are also «specific gender relations of dominance and subordination between

4 The idea that the male sex-drive explains the existence of prostitution is often found in sex buyers' claims of their need of it (Monto, 2000: 78-79; Barahona \& García, 2003: 92). To assert prostitution is a «social service» for men, means to implicitly assert that women ('s bodies) must be at the service of men ('s sexual needs). This is inherently misogynistic, incompatible with equality.

5 This does not constitute a fixed model. The change in definitions of masculinity, which depend on specific historical and social conditions, demonstrates «the historicity of gender» (Connell \& Messerschmidt, 2005).

6 They gain a patriarchal dividend «in terms of honour, prestige and the right to command», as well as a «material dividend» in terms of the control of capital (Connell, 1995: 82). 
groups of men». Homosexual masculinity is «the most conspicuous», but not the only subordinated masculinity (Connell, 1995: 78-79).

Within the context of patriarchal, capitalist societies, the concept of «patriarchal masculinity» denotes specifically the heterosexual, homophobic, violent type of masculinity (Salazar, 2012: 91) that refers to any masculine identity built upon the basis of men's dominance. It dictates men to comply with patriarchal expectations or face the threat of losing their masculine privileges. Sexuality has become a terrain where men test themselves as men, ${ }^{7}$ as they use sex to confirm their masculinity (Sambade, 2017: 170-171). Nowadays, neo-liberal capitalism ${ }^{8}$ has fed a narcissistic, hypersexualised and pornified masculine identity (Gómez, 2017: 151), which is partly based on the traditional account on male sexuality that allowed Mandeville to compare prostitutes to rotten meat.

The supposedly uncontrollable male sex-drive is a trait of patriarchal masculinity, and of what some authors have called «hegemonic sexuality», which is based on a «penis-centred model of sex». In a review of many contemporary studies of young men across class and ethnicity, it was suggested that «normative heterosexuality is constructed as a practice that helps to reproduce the subordination of young women and to produce age-specific heterosexual styles of masculinity, a masculinity centring on an uncontrollable and unlimited sexual appetite». This is the "grand story of male sexuality» based on an essentialising narrative that portrays men «as driven by sex; focused on their penises; in persistent need of orgasm; and often as borderline, if not actual, rapists» (Plummer, 2005: 179, 184, 186).

This does not mean all men experience sex according to that model -to assert that would imply falling into essentialist accounts all over again. It is a fact, though, that most men consider sex a significant «validation of their masculinity». Nowadays, the study of sex as just sex has gone from the agenda, ${ }^{9}$ as it conceals the fact that human sexualities are "forms of social actions», that individuals compose their sexual lives out of the social resources available (Plummer, 2005: 180-187). Feminist authors have critically addressed the reasons traditionally given to justify men's violence against women -which is crucial to challenge the patriarchal status quo. ${ }^{10}$ In the early 1980s, Adrienne Rich stressed the relevance of the scarcely questioned male sexual desire, which serves to justify sexual violence against women in its many forms:

7 Some authors have noted the importance of male peer pressure, used sometimes against men, for them to buy sex as part of the social ritual required to be accepted as «masculine» (Gómez et al. 2015: 22-23).

8 «Neo-liberalism is rhetorically gender-neutral» but «neo-liberal politics has no interest in justice at all». On the contrary, «neo-liberal regimes have been associated with a worsening in the position of women in most respects» (Connell, 1995: 254-255).

9 Structuralist criticism argued that sexuality was not a purely biological fact, but a socially constructed phenomenon. Foucault's work, particularly The History of Sexuality, is crucial in this respect for it examines the structures of language and discourse in the articulation of sexuality.

10 The feminist movement of the 1960s and 1970s criticised essentialist accounts of sexuality. Feminist theorists such as Kate Millet vindicated that also women have sexual desire and must be free to live their sexuality on their own terms. 
In the mystique of the overpowering, all-conquering male sex drive, the penis-with-a-life-of-its-own, is rooted the law of male sex right to women, which justifies prostitution as a universal cultural assumption on the one hand, while defending sexual slavery within the family on the basis of 'family privacy and cultural uniqueness' on the other. The adolescent male sex drive, which, as both young women and men are taught, once triggered cannot take responsibility for itself or take no for an answer, becomes, according to [Kathleen] Barry, the norm and rationale for adult male sexual behavior. [...] Women learn to accept as natural the inevitability of this 'drive' because they receive it as dogma (Rich, 2003: 134).

Research has shown that men with higher levels of entitlement think they deserve sex: «if that right/freedom is denied, entitled individuals react by interpreting this as a personal insult and with anger and anxiety» (Bouffard, 2010: 871). Bouffard's study found a significant association between higher levels of entitlement and the more traditional, stereotypical sex role attitudes, which positively correlated with hostility toward women. When male sexual proprietariness is threatened, coercion and physical violence become tactics in maintaining or regaining control. ${ }^{11}$ Thus, the notion of entitlement, especially gendered/patriarchal entitlement, should be incorporated in explanations of violence against women, ${ }^{12}$ and the link between certain male peer groups and violence against women should be further explored (Bouffard, 2010: 875). Since previous research shows a link between the endorsement of rape myths and buying sex (Farley et al. 2011), men's feelings of entitlement to prostitution must also be explored as part of the type of toxic masculinity linked to violence against women.

Prostitution use is predominantly a male practice and it must be conceptualised as a male issue: «in order to reach an understanding of what men seek in prostitutes, it is necessary to take into account men's sexuality and gender relations». Shifting the focus from women to men «leads to a radical consideration of men's responsibilities in prostitution» (Månsson, 2001: 135, 145). Why do men feel entitled to demand prostitution? As feminist scholar Sheila Jeffreys has pointed out: «An "idea of prostitution" needs to exist in the heads of individual men to enable them to conceive of buying women for sex», and «this is the idea that a woman exists to be so used, that it is a possible and appropriate way to use her. A necessary component of this idea is that it will be sexually exciting to so use a woman» (2008: 3).

Buying sex is not a biological urge of sorts. It is a very specific social practice that carries meaning at many levels and comes with a set of carefully studied actions (De Miguel, 2015: 176) -getting money, looking for a female prostitute, stay anonymous, etc- and a typical set of beliefs, an archetypical system of values that justifies the act of paying somebody to perform sexual acts that were otherwise

11 «Any strategy for the maintenance of power is likely to involve a dehumanizing of other groups» (Connell \& Messerschmidt, 2005: 852).

12 Sex buyers from Madrid have been quoted saying that society needs prostitution because it provides a "valuable social service», and that rape rates (of non-prostituted women) would increase if prostitution were to be banned (Barahona \& García, 2003: 92). 
unwanted. ${ }^{13}$ The non-reciprocal sex that takes place within prostitution satisfies those men that identify with the patriarchal type of masculinity (Sambade, 2017: 174). Thus, patriarchal socio-historical conditions must be taken into consideration in any analysis of prostitution-related practices. As feminist political theorist Carole Pateman put it:

Prostitution is now part of an international sex industry that includes massmarketing of pornographic books and films, widespread supply of strip-clubs, peep-shows and the like and marketing of sex-tours for men to poor Third World countries. The general display of women's bodies and sexual parts, either in representation or as live bodies, is central to the sex industry and continually reminds men - and women - that men exercise the law of male sex-right, that they have patriarchal right of access to women's bodies. [...] The story of the sexual contract suggests that the latter [the prostitution] demand is part of the construction of what means to be a man, part of the contemporary expression of masculine sexuality. [...] The exemplary display of masculinity is to engage in 'the sex act'. (Hence, sale of men's bodies for homosexual use does not have the same social meaning). The institution of prostitution ensures that men can buy 'the sex act' and so exercise their patriarchal right (Pateman, 1988: 199).

The male prostitute in heterosexual encounters cannot be equated to the female prostitute, because he has more autonomy, he is rarely if ever under the control of pimps and is not typically exposed to violence. The construction of masculinity within a patriarchal, capitalist context puts socially devalued bodies (women's, transsexuals' and gay or bisexual men's) at the service of the male hegemonic subject but, when it is characteristic of female prostitutes to provide the so-called «sexual services» for male sex buyers, most male prostitutes cater to male sex buyers as well. Importantly, this shows that the model of masculinity that sustains prostitution goes beyond sexual orientation and is potentially endorsed by any man (Ranea, 2017: 137).

Some studies focus on male prostitution as part of an analysis of the taboo surrounding (male) homosexual identity, concluding that "while violence towards female sex workers might be understood as having a misogynistic basis, violence towards male sex workers is best understood as having a homophobic or heterosexist basis»; thus, female prostitutes are stigmatised because they are women, but male prostitutes are stigmatised because they are homosexual (or assumed as such by their attackers) which means they are not attacked because they are men, but for representing «an affront to masculinity». Besides, most acts of homophobic violence are perpetrated by «groups of men who are unfamiliar to the victim», but violence of women against male prostitutes is not reported as an issue (Scott et al. 2005: 6-8).

Despite homophobic-based violence, studies conducted in Australia and Argentina showed that violence during a commercial sex encounter was a rare

13 The demand for money in the transaction is crucial, as it shows «that a woman's sexual compliance in the acts were otherwise unwanted» (Baldwin, 1992: 119). 
event in the experience of most male prostitutes (Scott et al. 2005, 20). Comparing their data with research on prostitution across nine countries -Canada, Germany, Colombia, Mexico, South Africa, Thailand, Turkey, the United States, and Zambiacarried out by clinical psychologist and prostitution researcher Melissa Farley and her team (2008b), whose findings indicated overwhelming physical and emotional violence in prostitution, proves that there is a qualitative difference between the experiences of male and female prostitutes. ${ }^{14}$

Indeed, studies show that women and transgender people are more likely than men to experience physical assault and rape in prostitution (Monto, 2004). To be female -or to be perceived as female- implies to be more intensely targeted for violence (Farley \& Barkan, 2008a: 41). Therefore, gender does qualitatively affect the experience of prostituted women and to regard it as if it were «gender neutral» is both idealistic and dangerous. Sex buyers' attitudes toward prostitutes need further scholarly attention, as these men are likely to hold beliefs linked to the perpetration of violence against women (Monto, 2004: 184).

Nowadays, the \#MeToo movement on social media seeks to challenge everyday sexual predation by men. Alisa Bernhard, who works at the Organization for Prostitution Survivors in the United States, has pointed out that everything women describe in the \#MeToo campaign are "common everyday experiences of women in prostitution». Since prostitutes are considered as a different caste of women created to guarantee men unconditional sexual access to female bodies, they are seen «as a legitimate target for men's violence, that we somehow deserve what we get» and, as Evelina Giobbe, prostitution survivor and founder of WHISPER -Women Hurt in Systems of Prostitution Engaged in Revolt- has noted, prostitution is set apart from everything that women are «me-tooing» about (Farley, 2018: 3).

\section{2.- Methodology and a note on terminology}

PunterNet offers two sections where users write openly, without mediation, about their experiences in the sex market: the Community Forum, which is quite miscellaneous and unstructured, and the «service provider» reviews. This research focussed on the reviews because of the specific type of discourse produced in them: by the men, about the women. They are structured for sex buyers to give information in a systematic way. ${ }^{15}$ After considering an approximate number of 200 reviews, 60 were selected as a manageable sample, and analysed. Thirty were labelled by sex buyers as «positive» and thirty as «negative» («Recommended»/«Not

14 In Australia and Argentina, 3.9\% and 1.7\% of male prostitutes reported violence, respectively (Scott et al. 2005: 20). Meanwhile, Farley's findings indicated that 70\%-95\% of women had been physically assaulted, $60 \%-75 \%$ had been raped in prostitution, $68 \%$ met criteria for Post-Traumatic Stress Disorder in the same range as treatment-seeking combat veterans, battered women seeking shelter, rape survivors, and refugees from state-organised torture (Farley et al. 2008b: 55).

15 «Details of Visit», including «Author», «Type of Visit» («Incall»/«Outcall»), «Date and Time of Visit», «Duration», «Amount Paid», «Recommended» («Yes/No/Neutral»); and «Details of Service Provider», including «Profile Name», «Website and Phone», «The Premises», «The Lady», «The Story». 
recommended»). The selection criteria were based on the amount and content of the information provided, aiming at selecting representative samples and finding patterns and characteristics of the positive/negative dichotomous way of reviewing women.

This study of sex buyers' discourse in online sex-trade websites was carried out by means of Critical Discourse Analysis. This methodology provides the adequate means to approach the issue in a systematic and critical way because it focuses on the importance of the relationship between discourse and power relations; it theoretically bridges the "gap» between the micro and the macrolevel in order to make explicit the connection between the practices belonging to the microphysics of power and social order as such (van Dijk, 2015: 468). Dominance may be enacted and reproduced by subtle, everyday forms of text and talk considered normal and acceptable. As van Dijk highlights, critical discourse analysts must take an explicit socio-political stance and undertake a political critique of the individuals responsible for the reproduction of dominance and the perpetuation of inequality.

In this paper, the selection of terminology that may somehow condone men's abuse of women is explicitly rejected. Sheila Jeffreys has pointed out the importance of the term «sex work» in naturalising men's purchase for sex and her intention of separating her approach from those trying to legitimate prostitution, for language is important in aligning a text with a specific perspective. She does not consider men's behaviour in choosing to use women in prostitution to be something natural, biologically-driven, but a behaviour that has been socially constructed out of men's dominance and women's subordination (Jeffreys, 2008: 3). She maintains that a term equivalent to batterer and rapist should be created to keep the light on buyers as perpetuators of prostitution but finds no effective term available that identifies the abusive behaviour.

The following terms were considered to address the men who purchase sex: «client», «customer», «punter», «john», «sex buyer», «prostitutor». The three first terms were disregarded because they belong to the ideological normalisation of women's potential abuse in prostitution. «John» is a word created by prostituted women that entails that men who buy sex are «generic males, indistinguishable one from another» (Jeffreys, 2008: 3). This term will be used occasionally. The most favoured terms were «sex buyer», which emphasises his role as buyer-stressing his economic power, something overlooked by the previous terms; and "prostitutor», suggested by prostitution survivor and abolitionist activist from Ireland, Rachel Moran:

Wherever a woman is prostituted, there are also the men who prostitute her. There is a word to refer to them, in the context of their actions, but that word is not in common usage at the time of this writing. Therefore, I would like people to pay attention to the term 'prostitutor' in the body of this text. It has been deliberately included here to refer to those men who have, until now, carried out a specific behaviour without having to bear the weight of the term that describes it (Moran, 2013: 98). 


\section{Analysis of buyer-authored reviews on prostituted women and girls ${ }^{16}$}

The positive reviews are characterised by positive appraisal. Through them, sex buyers advice each other about seeing women or girls that gave the socalled «good service» which, according to our analysis, is defined by her being «accommodating», «solicitous», «happy and willing to please» and allow him to do whatever he wants. The concept of masculinity is inherently relational: it exists in opposition to that of femininity (Gómez et al. 2015: 89). Traditionally, being active has been considered masculine, and being passive, feminine: in the context of this online community, the verbs in active form for men and passive form for women reveal a belief system that holds sex to be strictly a male terrain, in keeping with patriarchal masculinity.

The aim of the encounter is to satisfy men's expectations, both sexual and nonsexual (ego-related): they expect prostitutes to work on pleasing them in every sense. Since they appreciate that women obey their whims and set no limits, expressions such as «made an effort to handle it», «never asks you to stop», "she didn't complain», and different versions of them, are common and highlighted as positive. The presence of the notions of «facial», «deep throat» and «face fuck» (popular categories in porn websites) show the influence of pornography ${ }^{17}$ in the sexual preferences of sex buyers. Sometimes a highly valued sexual practice is enough to define what a "good service» is. For example, one defined as «superb service» simply for him to ejaculate on her face. Another defined having (unprotected) anal sex as «the best fuck he had», naming intercourse without condom «some bareback action» and «full service». ${ }^{18}$

There is a general identification between «dressing slutty», «being sexy» and «looking professional». Descriptions show the pervasive tendency to describe and fetishise body parts, clothes and make-up, and how those elements interact to define the «professionalism» in prostitution. An inherent problem with the sex buyers' notion of «being professional» is the type of «skills» inherent to the «job». Not only it is difficult to identify what these would be, but such «skills» are likely to be based on irreconcilable notions for sex buyers and prostituted women. Rachel Moran has reduced to three the necessary «skills set», which are very far from what entails «being professional» for the johns. These are: «The ability to control your reflex to vomit. The ability to restrain your urge to cry. The ability to imagine your current

16 In this article, «prostituted women» is generally favoured over «prostitute». The aim is to refer to women in prostitution primarily by their condition of women in a patriarchal context, rather than by their condition of prostitutes. That term brings perpetrators into the picture, since «somebody must be doing something to the woman for her to be "prostituted"» (Jeffreys, 2008: 3).

17 See Alario (2017) for the way in which pornography works as a mechanism for the perpetuation of patriarchy by configuring male sexual desire in gendered, non-egalitarian terms.

18 To be willing to pay more for sexual practices that put women in a very vulnerable position (for example, sex without condom), proves their lack of concern and respect and it is a form of violence. Unprotected sex within prostitution is a public health issue that puts prostituted women and girls at high risk. 
reality is not happening» (Moran, 2013: 225). The business-related terminology used by pro-prostitution campaigners ${ }^{19}$ is thus revealed to be an imperfect way of masking the abuse most women endure within the prostitution contract.

Some sex buyers use euphemisms, such as "getting to know better», «date» and «re-visit», for the act of paying a woman or girl for sex, performing a pseudoromantic play in which money buys him the total control of the situation (Gómez et al. 2015: 175). Referring to the payment euphemistically has been noted in some positive reviews, with formula such as «business was taken care of», in passive. Often, they do not mention the money at all. Sometimes, when he is satisfied with her, the word «whore» or expressions that would define "what a whore is» are used to define her positively, as in "This lady was born to be whore», "A true whore», or "a wonderful whore, filthy and responsive to virtually every form of sexual contact»-which shows their satisfaction when women put themselves at the service of men's pleasure by performing a role of hypersexualised femininity often found in pornography (Sambade, 2017: 177).

This kind of linguistic violence is part of «the means of violence» that men as a group hold and use to maintain power: men feel that they are «exercising a right», that they are authorised «by an ideology of supremacy» to the verbal abuse of women (Connell, 1995: 83). The use of that pejorative term also shows how they instrumentalise it to stigmatise female sexual activity, ${ }^{20}$ express their desire for women to act like (their definition of a) whore but despise them for complying with the role nonetheless, and thus reinforce the double standard. In a prostitutedprostitutor relationship, this is utterly contradictory for had he not paid her, she would have had no sex with him.

Some sex buyers openly make the link between her showing pleasure and a «performance» on her part, while others put a lot of emphasis on that it was «real». It is vital to take into consideration the research on women's experience in prostitution, particularly in this type of research which is per definition one sided as it focuses on the men's recounts. Research on sex buyers across different countries show most of them believe prostituted women and girls enjoy the type of sex that takes place within prostitution (Farley, 2011; Barahona \& García, 2003). But many ex-prostituted women have largely spoken about their feelings of degradation and self-hatred due to sex buyers' disrespectful, violent behaviour, about their shivering panic when they are about to meet a new «client».

19 Among the proponents of the legalisation and decriminalisation legal models -which are implicitly pro-prostitution- are the postmodern Left, liberal/sex work feminists, the neo-liberal Right, sex traffickers, pimps, brothel owners and sex buyers themselves -who are to have the best position under a legalisation/decriminalisation policy. Huge economic interests are behind the neo-liberal, business-like, discourse of most of those who defend prostitution is a job like any other. This includes governments: in 1998, the International Labour Organisation recommended governments to legalise prostitution to benefit from the revenues. Holland, Germany and New Zealand have already followed the ILO's advice (Ekman, 2013: 3).

20 In a sex-for-money context, so they are likely to hold the same belief system when judging nonprostituted women who have sex for the sake of it. 
Their testimonies show there is an abyss between the ways men and women experience prostitution, and one parallels the other. It is a circular trap: the women are required to fake pleasure; when they succeed, johns take their acting for real and derisively call them «true whores»; when they do not succeed, the men get disappointed and angry, because they require that women fake pleasure and succeed for them to construct a fantasy of sexual potency in keeping with patriarchal masculinity. A prostitution survivor has written:

It astounded me how many men genuinely thought I enjoyed the 'work'. [...] The men ringing asked me the most disgusting questions - like did I have a tight vagina, was I horny (yeah, right), did I like being fucked (you have to be kidding!), what turned me on, and did I have a shaved pussy. The questions really pissed me off, but I pretended on the phone that I just loved being asked them ('Mademoiselle', 2016: 129-130).

There is no evidence indicating prostitutors in PunterNet are more intuitive about female sexual pleasure than sex buyers from previous research, especially since buying sex can negatively affect men's behaviour toward all women, ${ }^{21}$ and that many sex buyers hold misogynistic beliefs and attitudes that support rape myths (Barahona \& García, 2003; Durchslag \& Goswami, 2008). Interestingly enough, our data indicate that certain linguistic strategies employed by sex buyers when reviewing online are strikingly similar to those used by the men of a study on convicted rapists' recount of their rapes, particularly the deniers' recounts (Scully \& Marolla, 2005). Their study gives insight on how men who are sexually aggressive construct reality. ${ }^{22}$ The belief that women «enjoy sex» regardless of the circumstances can be found in both cases.

These researchers used the concepts of accounts as a tool to organise and analyse the vocabularies of motive which the rapists employed to explain their actions. Their data showed $83 \%$ viewed themselves as non-rapists even after being convicted (Scully \& Marolla, 2005: 274). They relied on the same themes, stereotypes, and images, to support their own belief that women enjoyed being raped. Despite the extensive research that shows how highly traumatic it is to

21 A sex buyer has been quoted saying: «I have an easier time treating them worse. I had a girlfriend who would just moan during sex and she wouldn't talk dirty but then I asked her to, and she got better at it. Then I called her a nasty slam pig this one time and she stopped having sex with me. With prostitutes, you can call them anything... » (Farley et al. 2011: 18).

22 They view rape as behaviour that has been learned socially through interaction with others and assert that convicted rapists have learned the attitudes and actions consistent with sexual aggression against women. The process of learning includes the acquisition of culturally derived «vocabularies of motive», which can be used to diminish responsibility and to negotiate a non-deviant identity by making use of a linguistic device by which norm-breaking conduct is socially interpreted (Scully \& Marolla, 2005: 273). 
be raped, they were convinced women enjoy it nonetheless. ${ }^{23}$ The deniers raped because their value system provided no compelling reason not to do so. When sex is viewed as a male entitlement, rape is not seen as criminal. They concluded that rapists' justifications and excuses are backed up by the cultural view of women as sexual commodities, dehumanised and devoid of autonomy and dignity and that the sexual objectification of women must be understood as an important factor contributing to an environment that trivialises and facilitates rape (2005: 284-285).

Our data show that the cultural view of women pointed out by Scully and Marolla as having a major role in trivialising and facilitating rape is legitimated and reinforced by sex buyers' online discourse on prostituted women and girls. The «narcissistic delusion» that prostitution is her «free choice», or that «it was consensual» is the ideology that keeps prostitution «running smoothly» (Farley, 2018: 3). Most certainly:

[Prostitution] is not some magical arena of life where men decide to treat women as economic equals; women in prostitution are paid in an hour what other women are paid in a week or a day because it is the only way of ensuring they will allow themselves to be used as human masturbation devices. Their higher pay does not reflect gender parity; it reflects the difficulty involved in earning it (Moran, 2013: 204).

The very terminology is treacherous: despite wrapping the prostitution gendered relations with business-related terms aimed at justifying the purchase of sex as a mere "service», prostitutors do not want the women to have the professional behaviour of money-driven businesswomen. They like to believe that pleasing them must be «more» than just work. As «customers» who pay for a «service», they should expect the other party to be mainly keen on money, but what defines a «bad service» is precisely to be keen on money rather than on «having sex with customers». For the men, «being professional» entails to both behave in a traditionally feminine way and enjoy (rather, succeeding in pretending to enjoy) having sex with them. Seeing in women a «genuine» desire to please them is fundamental, for they want the exercise of economic power over women to buy the absolute female subservience on which their masculine ego feeds.

The categories of «the masculine» and «the feminine» are political categories (Gómez, 2017: 145). The relationship between hegemonic masculinity and hegemonic femininity highlights «the asymmetrical position of masculinities and

23 The authors speak about the case of a gang rape in which the victim had been abducted at knife point. According to two of the rapists she didn't resist: «She acted like she enjoyed it, but maybe she was just acting. She wasn't crying, she was engaging in it». One said she had been «friendly» to the rapist who abducted her. Also, thinking retrospectively: «She was scared and just relaxed and enjoyed it to avoid getting hurt». The authors note how, despite redefining the act as rape then, he still believed she enjoyed it. Even a man who raped five women at gun point and then stabbed them to death, said: "Physically they enjoyed the sex [rape]. Once they got involved, it would be very difficult to resist. I was always gentle and kind until I started to kill them. And the killing was always sudden, so they wouldn't know it was coming» (Scully \& Marolla, 2005: 283). 
femininities in a patriarchal gender order»; indeed, «gender is always relational, and patterns of masculinity are socially defined in contradistinction from some model (whether real or imaginary) of femininity» (Connell \& Messerschmidt, 2005: 848). In the context of prostitution, sex buyers pay for the enactment of a specific model of femininity that women and girls are expected to perform. By having sex with a woman who performs a role of «emphasised» or «authentic» femininity, sex buyers can reaffirm their masculinity (Ranea, 2017: 139). These men find in the demand for commercial sex an opportunity to fulfil their masculine identities (Gómez, 2017: 146) and, thus, prostitution becomes part of the gender socialisation processes that configure and reinforce gendered power relations (Gimeno, 2018: 15).

A «bad service» is defined by been keen on money, having sex in a «unenthusiastic», «dispassionate» manner, not appreciating an «enjoyable» sexual act, showing «complete indifference» towards the sex or the john himself and/or not being able to pretend he is smart and funny by laughing at his jokes. If a girl or woman fails to provide them with such «services», sex buyers decide that they are «not cut out» for being prostitutes. At this stage, it is worth highlighting that the things that sex buyers complain about in the negative (and in some positive) reviews have been emphasised in prostitution research for being survival mechanisms of girls and women involved in the sex trade.

Women with direct experience of prostitution have spoken about one of their major survival strategies: the need of dissociation (split their self between the «personal self» and the "prostituted self») making use of different tactics including the setting up of physical and emotional boundaries. ${ }^{24}$ Dissociation from the body has been defined as "leaving it emotionally when it is impossible to leave physically» (Coy, 2009: 68). It is a psychological defence strategy ${ }^{25}$ and a well-documented reaction to trauma -particularly sexual abuse. The need to distance the thinking, feeling self from the physical body was discussed by the women Coy interviewed as a coping mechanism during commercial sex exchanges. Many linked surviving sexual abuse in childhood with switching off from the body, later repeating these actions when involved in prostitution. Dissociation enabled women «to remain calm throughout each commercial sex encounter» until it became an automatic response (Coy, 2010: 69). Unlike the worker who tries to fight against alienation and separation from the product of her/his labour, alienation and separation for prostituted women is essential for survival, so they develop this «split personality»; in that sense, "prostitution is the epitomisation of alienation» (Edwards, 1996: 99).

Within the PunterNet community, «basic services» is the widespread notion that certain sex-related practices can be taken for granted. This notion is hugely problematic: it reveals that ideally, everything should be «on sale» and if not, there

24 Autumn Burris, founder of Survivors for Solutions, did not accept overnight appointments because she could not disassociate long enough to get through the night. «Disassociation became more normalised over time and with practice - a trick of the trade. I learnt to numb myself by using alcohol and drugs, an important tool in surviving» (2016: 136).

25 Rachel Moran has called it «the unplugging technique» (2013: 137). 
should be «basic services» that women must guarantee. This assumption derives from male entitlement to female bodies and compliance, and it is likely to have traumatic consequences for prostituted women and girls. Indeed, «the selling of sex is carefully circumscribed, certain behaviours and certain actions are taboo, certain bodily zones are out of bounds, and certain symbolic acts are reserved for loved ones»; this speaks more about what intimacy is, than about what sex is, which means many prostituted women might care more about the mouth, the lips, or kissing, than about the genitals and breasts (Edwards, 1996: 98).

Calling certain practices (kissing, hugging, sex without condom, anal sex, etc) that women reject to perform «basic services» trivialises their right to set up physical and emotional boundaries with whoever they do not want to intimate. By exposing publicly on PunterNet the women and girls that «do not provide certain services», sex buyers deny them that right, put pressure on other women and reinforce the assumption that «sexual services» are a (male) right. ${ }^{26}$ Fed in prostitution, these feelings of entitlement to a female subservient attitude are potentially dangerous to all women (Ranea, 2017: 136).

In both the positive and the negative reviews the women are systematically objectified. ${ }^{27}$ Violence is openly displayed in many instances. ${ }^{28}$ Signs of possible trafficking are either ignored or disregarded as irrelevant. ${ }^{29}$ Proponents of the legalisation and decriminalisation model have promoted the idealistic notion that women are free to choose their «clients» and set up limits. They should concern themselves with sex buyers' expectations. Unless, for whichever reason (class, race) women are in a privileged position, it is difficult for them to try to keep in control: the men actively try to control the situation themselves, and the economic power is on their side. To be able «to keep the job» may entail allowing johns to violate personal boundaries, when not having to deal with them imposing their conditions by force.

As it turns out, it is not «sex or sexual labour» which is exchanged in the prostitution contract. A sex buyer pays money to secure powers over the prostitute's person that he could not otherwise exercise: he pays for the prostitute «to make body orifices available to him, to smile, dance, or dress up for him, to whip, spank, urinate upon, massage, or masturbate him, to submit to being urinated upon, shackled, or beaten by him, or otherwise act to meet his desires» ( $\mathrm{O}^{\prime}$ Connell Davidson, 2002: 86). Our data indicate that when prostitutors face boundaries,

26 This is at the core of what has become known as rape culture, and it serves to justify prostitution, rape of both prostituted and non-prostituted women, coerced sex within marriage, etc.

27 Women are often compared and/or equated with objects or lifeless matter (blow-up doll, dead body, etc). It is common to comment on the "quality» of their vaginas and reduce the value of the prostitute and her «service» to that. Men compare vaginas not considered «small/tight» enough with inanimate things (bucket, tunnel, etc).

28 Sometimes, sex buyers quote women's words, but signs that they are in pain are met with sarcasm and contempt.

29 This is consistent with previous research that found the suspicion of trafficking and the awareness of prostitution negatively affecting women's lives are not considered as a deterrent for buying sex (Barahona and García, 2003; Durchslag \& Goswami 2008; Farley et al. 2011). 
they can write a negative review online and look for another «service provider»: a more «accommodating» one, or somebody who cannot afford saying no due to extreme social vulnerability. The aim is that she complies with male conditions, so it will always be more convenient for the average sex buyer to look for the most vulnerable.

Prostitution works as a homosocial terrain that generates a masculinity-based, prostitution-related subculture ${ }^{30}$ specific for sex buyers. Within the PunterNet community, the men's personal information is safeguarded by a "punter self», an identity strictly linked to the activity of buying sex and protected by their chosen nicknames. It is a strictly male peer group whose members support and reinforce hostile attitudes against women through their discourse. They are aware of sharing information about an activity socially constructed as a masculine privilege, and that they can use this online tool to publicly punish women who do not comply with their demands and expectations. In the homosocial subculture created through prostitution use, sex buyers reaffirm their belonging to a communitas of masculinity (Gómez, 2017: 154) with obvious patriarchal, toxic traits. Thus, this type of virtual communities may have an effect comparatively similar to the ones that are characteristic of other types of homosocial male groups, which have been said to be a potential broth for the kind of masculine attitudes that are likely to endorse and perpetrate violence against women (Connell, 1995).

The concept of «basic services» poses an additional problem to the idea of prostitution as «work». Since it involves sex, can the government legitimately regulate the sexual lives of individuals, of which individuals, under what principles ${ }^{31}$ and to what extent? If it is about work, workers' health must be protected, but how can women's health be protected from their customers' requirements under a policy of legalisation or decriminalisation which obviously disregards the questionable hidden aspects of buying sex by treating it as a legitimate practice? What practices must be considered part of the job? Could the government, prostituted women and sex buyers agree on them? Above all, is it legitimate that the physical and mental health of a contingent of women and girls must be put at risk of suffering daily violence, contracting venereal diseases, dealing with post-traumatic stress disorder if they survive, in order to provide the so-called «sexual services» some men demand?

\section{Conclusions}

As PunterNet exemplifies, virtual communities for sex buyers are a direct consequence of the gendered condition of prostitution-which exposes the enactment of patriarchal power relations in a particularly clear way, for it is based on socially and economically non-egalitarian conditions between men and women and on the

30 «Subcultura prostitutiva» or «subcultura putera» in Spanish (Gómez et al. 2015).

31 The defence according to which the male, heterosexual population has the need and the right to (buy) sex from whoever they want, means that a contingent of women must be systematically denied their own need and right to have sex with whoever they want. 
«male sex-right» that ensures men's access to women's bodies (Pateman, 1988)and the development of modern technologies. These communities allow men to share different aspects of purchasing sex in an anonymous, safe environment. A typical trait of them is the option of writing public reviews.

Beyond other aspects of prostitution as a gendered practice, there are not mass-scale, culturally equivalent online communities for female sex buyers of male prostitutes where heterosexual women discuss sex purchase and rate male prostitutes publicly: only men have the opportunity to produce such a discourse at a large scale, which means they have total control over this type of context and its social consequences. Importantly, such opportunity is granted to men as a group. There is not a specific profile or prototype for those individuals that buy sex, apart from being male and heterosexual (Barahona \& García, 2003; Gómez et al. 2015), showing an utter lack of empathy toward women, and using sex to reaffirm their patriarchal masculinity (Sambade, 2017: 175). Ultimately, sex buyers' discourse reproduces gendered power relations based on the social dominance of men over women. Even after new forms of sexualities have appeared, the act of paying for sex continues to be a male privilege in patriarchal societies, that can now coexist with both the traditional type of masculinity and the new emergent ways of «being a man» (Gómez, 2017: 151).

There are two core pieces to prostitution: one party wants sex, and has money, the other does not, but needs money. The economic power enacted in the act of buying sex cannot be ignored: the payment symbolically and effectively excludes female sexual pleasure (and, a priori, women's own conditions in general) from the prostitution contract. The positive reviews epitomise a conscious eroticisation of masculine dominance on the part of prostitutors. The traits highlighted as positive belong to the semantic field of (female) serviceability, hegemonic femininity, and the feeding of patriarchal masculinity. Sex buyers pay for female sexual desire not to count and for women to relinquish their freedom, which makes them feel they have the «right» to not respect her boundaries. They demand to see the confirmation of the masculine superior status in the prostitute's behaviour.

Their anger and resentment arise when their expectations of dominance are not met. They never take responsibility for their role as sex buyers -even in cases where control by pimps was evident, something in clear contradiction with the free exercise of the "profession». The self-indulgent objectifying language characteristic of the positive reviews turns into an overtly violent language in the negative ones, indicating traits of a hostile type of masculinity which reveals misogynistic attitudes that come close to violence against women. Thus, there is evidence from the buyers themselves supporting the claims made by anti-prostitution researchers and abolitionist survivors according to which it is a degrading and violent practice rather than «just work». Prostitution dehumanises women, not because they «dehumanise themselves» by being involved in prostitution, but because of sex buyers' tendency to objectify and dehumanise them. The potentially dangerous consequences this may have on men's actual encounters with them cannot be regarded as irrelevant. 
Face-to-face interactions between men and women would need to be fair and equal for «sex workers» not to suffer male violence under a policy of decriminalisation or legalisation. However, sex buyers' recounts indicate they regard the objectification and dehumanisation of women as inherent to prostitution. These work as mechanisms of domination that both satisfies them sexually and reaffirms their masculinity (Sambade, 2017: 171). Sex buyers' construction of an ideal type of heterosexual liaisons based on the notion of "good service», in which female (real) sexual desire is not rendered as necessary for sex to take place, is likely to feed their feelings of entitlement to non-consensual sex and to negatively affect their relations with women outside the context of prostitution too. The money factor blurs the meaning of the "no is no» feminist mantra that aims at making men respect women's sexual freedom and boundaries in any context besides and beyond prostitution.

Feminist sociologist Kathleen Barry wrote about the many times she felt as if her heart would break at seeing how society accepts the abuse of women - an emotion that men condemn as «a failure of objectivity». And yet, she realised that it was the stifling of such emotion that creates the conditions of violence and slavery, and that «emotionless objectivity leads directly to objectification -the starting point of violence, and particularly sexual violence» (Barry, 1979: 215). Feminist scholar Margaret A. Baldwin has also written about the "great anguish and frustration» in her attempt «to render women's pain into words, cast to the kindness of strangers» (Baldwin, 2006: 108). Certainly, facing that prostitution allows men to buy the right to sexually abuse women and girls can be emotionally damaging, and many people turn away from the brutal daily reality of prostitution. But it is time for the voices of prostituted women to be included in movements such as the \#MeToo campaign, because they are abused daily, and because prostitution "sets the parameters for what you can do to a woman», so it «is the model for women's condition» (Farley, 2018: 2).

The dominance of men is a historical process that is open to challenge. Since hegemonic masculinities are subject to historical change, older forms of masculinity can be «displaced by new ones» and it is possible that «a more humane, less oppressive, means of being a man» becomes hegemonic, «as part of a process leading toward an abolition of gender hierarchies» (Connell \& Messerschmidt, 2005: 833). In the same way, human sexuality is not biologically fixed, but symbolic, meaningful and linked to power. Sex is never just sex: «it does not exist in a social vacuum but is flooded with the social» (Plummer, 2005: 187). Currently, the traditional model of sex has been challenged from many sides and it can be said to have been replaced by a new model which is not focused on the qualities that characterise the model of the hegemonic male sexuality, which is, nonetheless, still very much linked to gender power relations and tends to presume the idea of a male heterosexual identity. Indeed, women are "repositioning themselves in relation to power» and this "pushes the definitions of male sexualities» (Plummer, 2005: 190). Although this is true in many ways, our data indicate sex buyers look for the confirmation of the "grand story of male sexuality» in prostitution. 
Some authors have noted that, nowadays, there is a sense of crisis among men due to the social advances of the global women's rights movement (Gómez, 2017: 154). There are strong regressive, anti-feminist reactions and behaviours which express «an obvious feeling of loss and a need to compensate for this through suppressing or misdirected aggression to women in various contexts»: the rising demand for prostituted women and girls can probably be seen in the light of this «relative loss of gender power» (Månsson, 2001: 145). Men know that, in prostitution, they can legitimately request a self-coerced, subservient role of women and enact traditional gender roles without being effectively challenged. Consequently, prostitution damages all women by providing a locus for the enactment of a type of masculinity with overt misogynistic bias, where male ego and his sexual fulfilment are central and where money buys the right to disregard women's sexual desire, health and wellbeing.

Ultimately, legally legitimising the enactment of men's economic power to buy a masculine fantasy based on non-egalitarian conditions implicitly supports, justifies and perpetuates gender inequality and violence against women at a larger scale. A legal model that targets the demand for prostitution, which has become known as Nordic model, has the potential to help redefine the "socially admired masculinity» and «to establish as hegemonic among men a version of masculinity open to equality with women» (Connell \& Messerschmidt, 2005: 846, 853). Most definitely, raising the new generations of men in a different type of masculinity is rendered necessary for the achievement of social equality between men and women.

\section{Bibliography}

Alario Gavilán, Mónica (2017). «Pornografía en un patriarcado neoliberal: ¿una cuestión de deseos individuales?» in NuÑo Gómez Laura y Ana De Miguel Álvarez (dirs.) (2017). Elementos para una teoría crítica del sistema prostitucional, Granada: Comares. pp. 181-191.

BAldwin, Margaret A. (2006). «Split at the Root. Prostitution and Feminist Discourses of Law Reform» in SPector, Jessica (ed.) (2006). Prostitution and Pornography. Philosophical Debate about the Sex Industry, Standford: Standford University Press., pp. 106-145.

Barahona Gomariz, María José and Luis Mariano García Vicente. (2003). Una aproximación al perfil del cliente de prostitución femenina en la Comunidad de Madrid, Madrid: Publicaciones DGM.

BARry, Kathleen (1979). Female sexual slavery, New Jersey: Prentice-Hall.

BoufFARD, Leana Allen. (2010). «Exploring the utility of entitlement in understanding sexual aggression» in Journal of Criminal Justice, vol. 35, no 8, pp. 870-879.

Burris, Autumn (2016). «No Life for a Human Being» NormA, Caroline and Melinda Tankard Reist (eds.) (2016). Prostitution Narratives, Victoria: Spinifex Press Pty Ltd, pp. 136-140. 
Carter, Vednita and Evelina Giobbe. (2006). «Duet: Prostitution, Racism and Feminist Discourse» in SPECTOR, Jessica (ed.) (2006). Prostitution and Pornography. Philosophical Debate about the Sex Industry, Standford: Standford University Press., pp. 17-39.

Сово, Rosa (2017). La prostitución en el corazón del capitalismo, Madrid: Catarata.

Connell, Raewyn W. and James W. Messerschmidt (2005). «Hegemonic Masculinity: Rethinking the Concept» in Gender $\mathcal{E}$ Society, no 19, pp. 829-859.

Connell, Raewyn W. (1995). Masculinities, Cambridge: Polity.

Cor, Maddy (2009). "This body which is not mine. The notion of the habit body, prostitution and (dis)embodiment» in Feminist Theory, vol.10(1), pp. 61-75.

De Miguel Álvarez, Ana (2015). Neoliberalismo sexual: el mito de la libre elección, Madrid: Ediciones Cátedra.

Durchslag, Rachel and Samir Goswami. (2008). «Deconstructing the Demand for Prostitution: Preliminary Insights from Interviews with Chicago Men Who Purchase Sex» Chicago: Chicago Alliance Against Sexual Exploitation.

EDwARDS, Susan (1996). «Selling the Body, Keeping the Soul: Sexuality, Power, the Theories and Realities of Prostitution» in Scott, Sue and David Morgan (eds.) (1996). Body Matters: Essays on the sociology of the Body, London \& Washington: The Falmer Press.

Ekis EKMAN, Kajsa (2013). Being and being bought: Prostitution, Surrogacy and the Split Self, Victoria: Spinifex Press Pty Ltd.

FARLEY, Melissa (2018). «\#MeToo Must Include Prostitution» in Dignity: A Journal on Sexual Exploitation and Violence, vol. 3, issue 1, article 9.

FARLEY, Melissa et al. (2011). «Comparing Sex Buyers with Men Who Don't Buy Sex: "You can have a good time with the servitude" vs. "You're supporting a system of degradation." » Paper presented at the Annual Meeting of Psychologists for Social Responsibility, Boston. San Francisco: Prostitution Research \& Education.

FARley, Melissa and Howard BARKAN (2008a). «Prostitution, Violence, and Posttraumatic Stress Disorder» in Women E Health, 27:3, pp. 37-49.

FARLEY, Melissa et al. (2008b). «Prostitution and Trafficking in Nine Countries» in Journal of Trauma Practice, 2:3-4, pp. 33-74.

Gimeno, Beatriz (2018). «La nueva utilidad de la prostitución en el neoliberalismo» en Atlántidas. Revista Internacional de Estudios Feministas, 3(1), pp. 13-32.

Gómez SuÁrez, Águeda (2017). «Masculinidad y gramática sexual del "putero"» in Nuño Gómez Laura y Ana De Miguel Álvarez (dirs.) (2017). Elementos para una teoría crítica del sistema prostitucional, Granada: Comares. pp. 143-156.

Gómez SuÁrez, Águeda, Silvia Pérez Freire and Rosa María Vergugo Matés (2015). El putero español. Quiénes son y qué buscan los clientes de prostitución, Madrid: La Catarata.

Grant, Charlotte (2012). "Visible Prostitutes: Mandeville, Hogarth and "A Harlot's Progress" » in LewIS, Ann Marie and Markman Ellis (eds.) (2012). Prostitution and eighteenth-century culture: sex, commerce and morality, London: Pickering \& Chatto. 
«Harriet Harman tells Arnold Schwarzenegger to shut down website which tells punters to rate prostitutes» in Daily Mail online (2009). Retrieved from: http:/ / www.dailymail.co.uk/news/article-1217222/Website-allows-punters-rateprostitutes-performance-closed-says-Harriet-Harman.html\#ixzz4hNCwC5WZ. (Last accessed 01/05/19).

JefFreys, Sheila (2008). The idea of prostitution, Melbourne: Spinifex Press Pty Ltd.

'Mademoiselle' (2016). "Goodbye Mademoiselle» in Norma, Caroline and Melinda Tankard Reist (eds.) (2016). Prostitution Narratives, Victoria: Spinifex Press Pty Ltd, pp. 112-135.

MÅnsson, Sven-Axel (2001). «Men's Practices in Prostitution: The Case of Sweden» in Pease, Bob and Keith Pringle (eds.) (2001). A man's world? Changing Men's Practices in a Globalized World, London: Zed Books. pp. 135-149.

May Larry (1998). Masculinity $\mathcal{E}$ morality, Ithaca, New York: Cornell University Press.

Monto, Martin (2004). «Female Prostitution, Customers, and Violence» in Violence Against Women, vol. 10.1177, pp. 160-188.

Monto, Martin A. (2000). "Why men seek out prostitutes» in WeITzER, Ronald (ed.) (2000). Sex for sale: prostitution, pornography, and the sex industry, New York: Routledge, pp. 67-83.

Moran, Rachel (2013). Paid for. My Journey Through Prostitution, Dublin: Gill \& Macmillan.

O'Connell Davidson, Julia (2002) «The Rights and Wrongs of Prostitution» in Hypatia Vol 17, no. 2, pp. 84-98.

Pateman, Carole (1988). The Sexual Contract, Standford: Standford University Press. Plummer, Ken (2005). "Male sexualities» in KImmel, Michael, Jeff HeARN and Raewyn W. Connell (eds.) (2005). Handbook of Studies on Men E Masculinities, California: Sage Publications, Inc., pp. 178-195.

PunterNet. Retrieved from: http://www.punternet.com/index.php (Last accessed 22/1/19).

RANEA Triviño, Beatriz (2017). «(Re)pensar la prostitución desde el análisis crítico de la masculinidad» in NuÑo Gómez Laura y Ana De Miguel Álvarez (dirs.) (2017). Elementos para una teoría crítica del sistema prostitucional, Granada: Comares. pp. 135-142.

RicH, Adrienne (2003). «Compulsory Heterosexuality and Lesbian Existence» in Journal of Women's History, vol. 15, no 3, pp. 11-48.

SAlAzAR, Octavio (2017). «Prostitución y desigualdad: la necesaria deslegitimación de los sujetos prostituyentes» in NuÑo Gómez Laura y Ana De MiguEL Álvarez (dirs.) (2017). Elementos para una teoría crítica del sistema prostitucional, Granada: Comares. pp. 157-168.

SAlAzAR, Octavio (2012). «Otras masculinidades posibles: Hacia una humanidad diferente y diferenciada» en Recerca, 12(6), pp. 87-112.

Scotт John et al. (2005). "Understanding the new context of the male sex work industry» in Journal of Interpersonal Violence, 20(3), pp. 320-342. 
Scully, Diana and Joseph Marolla (2005). «Convicted Rapists' Vocabulary of Motive. Excuses and Justifications» in Pontell, Henry (ed.) (2005). Social Deviance. Readings in Theory and Research, Upper Saddle River: Prentice Hall.

SENENT, Rosa M. (2017) «He who pays the piper calls the tune: masculinity and sex purchase online - a critical discourse analysis» (MA thesis Erasmus Mundus Master's Degree in Women and Gender Studies). University of Oviedo, Spain/ University of Łódź, Poland.

Van DijK, Teun (2015). «Critical Discourse Analysis» in TANnEN, Deborah (ed.) (2015). The Handbook of Discourse Analysis, Second Edition, Hoboken: WileyBlackwell.

Recibido el 30 de enero de 2019

Aceptado el 6 de junio de 2019 BIBLID [1132-8231 (2019): 23-43] 